African Research Review vol.1(1)

\title{
Sales of Medicinal Forest Tree Barks in Abeokuta, Ogun State Nigeria
}

\author{
E.O.A Oluwalana, Dr. M.F. Adekunle and A.A. Ayeni
}

\begin{abstract}
The marketing of forest tree barks used for medicinal purposes were investigated in some markets in Abeokuta metropolis. This was to provide the much needed information on the sellers, buyers and producers of these products for sustainable production and maximum socio-economic benefits.

This study identified 43 species being sold in the market places sampled namely Kuto, Omida, Itoku, Lafenwa, Iberekodo and Elega. Almost the same species were traded in all the markets sampled. This study further revealed that the trade of forest tree barks is pre-dominated by women accounting for $93.3 \%$ of the total respondent. Fifty one percent of the respondents were recorded among the youths between the ages of 15 and 20 years old. Forest tree bark sales were found to contribute to the monthly income of the respondents. For instance more than half of them earned between N7,500 and N10,000 as monthly incomes from bark sales. A total of 62 or $41.33 \%$ or the total respondents were found to earn more than the State Government minimum wage of N4,600 monthly.

The Chi-square statistical analysis showed that there was a relationship between income earned by the respondents and the location of the markets.
\end{abstract}

\section{Introduction}

When one thinks of the productivity of a forest, the first thing that comes to mind is timber. The production of timber is often organized and highly visible and the markets for woods are highly structured, organized and well established.

Forests also produce a multitude of other products (NWFPs) (FAO 1995, Popoola and Oluwalana, 2001). This includes diverse items such as medicinal plants and materials, natural dyes, mushrooms, honey, latexes, gum resins, leaves, barks, fruits and many others. NTFPs have the potential to become substantial sources of revenue for many households but in many developing countries such as Nigeria, they are under exploited with respect to revenue generations. Although considerable use is being made of these products by people but their commercial value is low. Popoola and Oluwalana (2001) stated that forests are frequently under-valued because a wide range of other NTFPs are not included in traditional financial and economic analysis of forest projects. Under-valuation encourages deforestation and also encourages Governments to assign low priority to and marketing of hitherto dominated the rural economies. They are now making a 'forceful' incursion into the semi-urban and urban economies. However, there is little or no researches in place to ascertain the total economic values (TEV) of this very important segment of the forestry sub sector. Added to these is the inadequate knowledge by villagers and middlemen of NTFP development.

The importance of marketing information on NTFPs therefore cannot be overemphasized if a holistic approach to the development of the NTFPs segment of the forestry sub sector is to be enhanced.

The focus of this study therefore, is to carry out a market survey on the sales of medicinal forest tree barks in some markets in Abeokuta. Barks have been defined biologically (Dutter, 1981) as all the dead tissues lying outside the active cork cambium of the plant. They are classified into ring and scale barks. Barks perform some biological functions to the plant. Its basic function is protection because it is a hard dry covering for the plant. It protects inner portion from the attacks of insects and fungi, against loss of water by evaporation and against the variation of external temperature. Some green barks of plants are photosynthetic in nature. 
Apart from biological function of barks, they also perform some socio-economic roles in the life of people. This has been notable as important ingredients in the preparation of herbal and traditional medicines for health care delivery. Medicinal plant materials especially bark comprise one of the major NTFPs categories on the marketing of which information is scarce. This is inspite of prime of place attached to tradition systems of health care these days especially in Ogun State where the dearth of orthodox systems of medicare have been reported (Adekunle, 1992). The use of forest tree barks to cure ailments has been widely reported by other authors. For instance the barks of Enantia chlorontia, Khaya ivorensis, Mangifera indica, Psydium guajava and Alstonia boone $i$ have been report efficacious in the local treatment of malaria fever and pile. Plant materials such as barks contain different active ingredients, which are extracted for medicinal purposes. Some of the method of extraction include decoction, infusion, maceration and tinctures (Adebisi, 1999).

The increasing interest in tradition systems of medicare using forest plants and the continuous importance of NTFP as a source of income and employment for the people has led the people to harvest medicinal materials for various markets and in most cases unsustainably. Hence the relevance of this study as it will provide information on some forest tree barks sold in Abeokuta markets.

The term markets though a mental concepts, have been defined as outlet for produce and services. According to Added Veld (2000), the market is a specific location where buyers and sellers meet. Suppliers offer their goods, consumers look, compare and buy. Marketing on the other hand involves finding out what the customer want and helping to set up the production and marketing systems that meet demand and maximize income. The term market in this paper to describe the locations where tree barks are on display for sale.

\section{Methodology}

This study was carried out in Abeokuta, the home of the Egbas' and capital of Ogun State. The town is situated at the Abeokuta North and South Local Government Area. Details about the socio-cultural and demographic characteristics of Abeokuta town have been described by Onakomaiya et al, (1992), Adekunle and Oluwalana (2000).

One hundred and fifty structured and pre-tested questionnaires were administered to herbal sellers in six market places randomly selected with at least three in each of Abeokuta North and South Local Government Areas in which the town is situated (see Table 1).

The questionnaires sought to know among other things the different species from which tree barks are extracted for sale and the pricing systems. Information was also collected on income and bio-data of the respondents.

Apart from collecting data through questionnaires, visual observations were made and notes taken during formal and informal discussion with respondents. This helped to provide insights into the markets. The sample frame is stated below. The local names of the plants were recorded while taxonomic tests such as Gbile (1984) were consulted for the botanical names of the plants.

The data collected were analysed separately and later pooled. Some descriptive statistical tools like frequencies, mean and percentages were adopted for the variables of interest. The Chi-Square test at 5\% level of significance was also adopted to test for 
association between Market place and corresponding income earned by medicinal herb sellers. The results are presented in form of tables for discussions and recommendations.

Table 1Sample frame for survey of medicinal tree barks in Abeokuta

\begin{tabular}{|c|c|c|}
\hline L.G.A & Name of markets & No. of respondent \\
\hline Abeokuta North & Iberekodo & 25 \\
\hline & Lafenwa & 25 \\
\hline \multirow{2}{*}{ Abeokuta North } & Ita Elega & 25 \\
\hline & Omida & 25 \\
\hline & Kuto & 25 \\
\hline Total & Itoko & 25 \\
\hline
\end{tabular}

\section{Results and Discussion}

Table 2 gives the summary of the gender distribution of the respondents. It could be observed that majority of them were females representing $93.33 \%$ of the total. This could be as a result of the fact that women are more predisposed to buying and selling in the southwestern Nigeria. It could also be that most men prefer their wives to be involved in sedentary occupation especially selling of wares in shops and kiosks. The system of pricing was mainly by haggling between seller and buyers until the acceptable price by both parties are reached.

Of the 150 respondents, 77 or $51.3 \%$ were found to be above 30 years of age. The least number of 12 or $8 \%$ was recorded among the youths of between 15 and 20 years old (Table 3). This trend could be as a result of the fact that the young ones are now taking to herb ware sales probably due to unemployment. It could also be as a result of the older ones becoming inactive as a result of old age. Popoola and Ajewole (2001) observed that there is more awareness as more people among urban residence are becoming conscious of the safety and efficacy of herbs in primary health care delivery. It is assumed that these young ones might take over from their parents in the sale of medicinal plant materials. The knowledge of medicinal plant use and sales have been reported to have been passed from parents to their children by Okafor (1990) in the South Eastern Nigeria. This finding is also in line with Adekunle (1992) in respect of indigenous knowledge transfer from elders to the young ones in Ogun State.

Educationally, about 61 or $41.3 \%$ of the total respondents were primary six certificate holders, 54 or $36 \%$ were school certificate holders while only 14 or $9 \%$ of the respondents had no formal education. Only one respondent had post-secondary education. Quaranic school leavers accounted for 14 or $12.7 \%$ of the total respondent (Table 4).

The large occurrence of literate respondents could be because of high literacy level in Abeokuta town as the city had been adjudged as the cradle of education in 
Nigeria. A large percentage of literates in the society might enhance afforestation campaign.

Table 2: Sex of Respondents

\begin{tabular}{|l|c|l|}
\hline Sex & Frequency & Percentage \\
\hline Male & 10 & 6.67 \\
\hline Female & 140 & 93.33 \\
\hline Total & 150 & 100 \\
\hline
\end{tabular}

Table 3:Age of Respondent

\begin{tabular}{|c|c|c|}
\hline Age Group & frequency & Percentage \\
\hline $15-20$ & 12 & 8.00 \\
\hline $21-25$ & 14 & 9.33 \\
\hline $26-30$ & 47 & 31.33 \\
\hline Above 30 & 77 & 51.34 \\
\hline Total & 150 & 100 \\
\hline
\end{tabular}

Source: Field survey, (2002)

Table 4: Educational Status of Respondents

\begin{tabular}{|c|c|c|}
\hline Educational Attainment & frequency & Percentage \\
\hline Primary Six & 61 & 41.33 \\
\hline S.S.C.E. & 54 & 36.00 \\
\hline Post Secondary & 2 & 0.67 \\
\hline Quaranic School & 19 & 12.67 \\
\hline No Formal Education & 14 & 9.33 \\
\hline Total & 150 & 100 \\
\hline
\end{tabular}

Source: Field survey, (2002)

\section{Income Distribution of Respondents}

Table 5 shows the monthly distribution of the respondent sellers of medicinal tree barks. According to the table, a large number of the respondents 88 or $58.67 \%$ of total earned less than N5,000 per month and are in the low scale category as far as the sales of the commodity is concerned. The least number of respondents 21 or $14 \%$ of the total respondents above N10,000 per month and were in the large scale sellers category.

Two categories of market were defined during this study i.e. semi-rural and urban. The semi-rural markets were Iberekodo, Lafenwa and Ita-Elega Markets all located in Abeokuta North LGA while Omida, Kuto and Itoko herbal markets were urban in nature 
and located in Abeokuta South Local Government Area. Table 5 shows the distribution of the markets into the two market types and the scale of bark sales observed.

The largest number of respondent sellers (14) earning above N10,000 were found in Elega market, Omida market had 4 respondents in this income bracket (Table 6). This could be because the two markets are close to where majorities of the elites are living. The popular Ibara and Elega Housing Estates are inhabited by the elites who can afford to buy 'at any price' when under pressure. This could also be because the elite classes are now involved in the use of traditional system of health care. The dearth of orthodox systems of medicare had earlier been reported in Ogun State (Adekunle 1992, 2005). This situation is being worsened by the incessant industrial unrest by medical workers in the State and Nigeria. Table 5 further revealed that a total of 41 or $27.33 \%$ of the total respondents earned between N5,000 and N10,000 monthly from bark sales. This is above the minimum wage being paid to State government employees. This is an indication that trades in forest NTFP such as tree barks could provide full time employment if well developed. Momoh et al., (1999) made similar observations in the study of trade in Abura leaves (Hallea citiata) in Omo forest reserve, Ogun State. They found out that the net profit from the trade in Abura leaves by three different categories of firms were higher than the monthly minimum wage of N3,000 being paid by the State government.

A total of 43 species had their barks on sales in the different markets were recorded (Table 7, Appendix 1) medicinal purposes. Nearly the same types of species were sold in all the markets visited but with varying frequencies (Appendix 1). The management implication of this is that should the sources of their wares be destroyed as it is being experienced in the forest areas, these sellers might loose their means of livelihood.

The Chi-square test at 5\% level of significance was used to test the null hypothesis that "there is no association between the market location and the income earned". The result of the hypothesis revealed that there is an association between the location of the market and the income earned. This is to say that the observation in Table 4 is not due to chance or random variation. Therefore the observation is statistically supported.

\section{Conclusion}

This study has shown that marketing of medicinal forest tree barks is an incomegenerating venture especially for young women in Abeokuta. It can provide full time employment if well developed as almost half of the respondents are earning above the State minimum wage from bark sales. The forests are the natural repositories of wild medicinal plants as similarity expressed by other authors like Adekunle (1992, 1998), Popoola and Ajewole (2001). It also revealed that the youths and literates are more involved in herbal sales in Abeokuta. This is an implication for environmental conservation for sustainable use of the resources. It should be borne in mind that forest begins with trees, therefore trees should be planted and abuse of the natural forest should be frowned at. The high level of literacy among herbal material traders could be an advantage to propagate the campaign for environmental resources conservation for sustainability. Tree planting campaign should be stepped up in Abeokuta and the government should provide highly subsidized tree seedling to farmers to encourage them. 
Table 5:Income distribution of respondents according to scales of bark sales.

\begin{tabular}{|c|c|c|c|}
\hline Income Group & Low Scale & Medium Scale & Large Scale \\
\hline$<5,000$ & $88(58.6 \%)$ & -- & -- \\
\hline $5,000-10,000$ & -- & $41 \quad(27.33 \%)$ & -- \\
\hline Above 10,000 & -- & -- & $21(14 \%)$ \\
\hline
\end{tabular}

Source: Field survey, 2002

Table 6: Categorisation of Herbal markets in the study area.

\begin{tabular}{|c|c|c|c|c|}
\hline Name & Rural & Semi Rural & Urban & Size \\
\hline Iberekodo & - & “"' & - & Small \\
\hline Lafenwa & - & 669 & - & Small \\
\hline Ita-Elega & - & 669 & - & small \\
\hline Omida & - & - & Urban & Medium and large \\
\hline Kuto & - & - & 6 & Medium \\
\hline Itoko & - & - & $6 " 9$ & medium \\
\hline
\end{tabular}

Source: $\quad$ Field survey, 2003

Table 7: $\quad$ Table showing number of species whose barks are on sales

\begin{tabular}{|l|l|l|l|l|l|l|}
\hline Markets & Omida & Kuto & Lafenwa & Itoku & Elega & iberekodo \\
\hline No. of species & 36 & 30 & 42 & 35 & 43 & 43 \\
\hline
\end{tabular}

References

Adebisi, L.A. (1999) Biodiversity conservation and ethnobotany of selected sacred groves in Osun State, Nigeria. Ph.D. thesis, Dept. of Forestry Resources Management, University of Ibadan, Ibadan, Nigeria (Unpublished) 198pp.

Adde, V. (2000) Marketing for small scale producers. Netherlands, CTA Agroodok - series No. 26.

Adekunle, M.F. (1992) Traditional medicines and wildplant conservation. A case study of Ogun State, Nigeria. B. Forestry thesis, Dept. of Forestry, University of Agriculture, Abeokuta, Nigeria (Unpublished) 158pp.

Adekunle, M.F. (1998) Survey of NTFPs and their user in Ogun State, Nigeria: A case study of Omo Forest Reserve. M.F. thesis, Dept. of Forestry, University of Agriculture, Abeokuta, Nigeria (Unpublished) 158pp.

Adekunle, M.F. (2005) Economic valuation of forest plants used traditional treatment of guinea worm (Dracunculus medinensis Linn) infections in Ogun State, Nigeria. Ph.D. thesis, Dept. of Forestry and Wildlife Management, University of Agriculture, Abeokuta, Nigeria (Unpublished 199p.

Ajewole, A. and Popoola, L. 2001: Public perception of urban forest in Ibadan, Nigeria implications for environmental conservation. Britain, Arboricultural Journal Vol. 25 pp. $1-22$.

Dutta, A.C. 1981: Botany for degrees students. Delhi, Bombay, Oxford University Press,

F.A.O. 1995: Forests, Trees and People (FTP), Newsletter, No. 29 FAO 1005 pp 22 - 27.

F.A.O. 1998: Marketing of indigenous medicinal plants in South Africa: A case study of Kwazulu - Nata. FAO, Rome, 1998. 150pp. 
Okafor, J.C. 1990: Utilization and conservation of medicinal plants in South Eastern Nigeria. The Bio prospector; 1(1) April, 1991: 6 - 14.

Onakomaiya, S.O. (ed.) 1992: Ogun State in Map, Rex Charles Publications, Ibadan, Nigeria p 29.

Momoh, S., Dipeolu, A. and Olakunori, B.B. 1999: The contribution of Trade in Abura (Hallea ciliata) to Household income in Area J4 Forest Reserve, Ogun State, Nigeria. Journal of Tropical Ethno-forestry 2 (1): $34-40$.

Popoola, L. and Oluwalana, S.A. (2001): Marketing of NTFPs in Nigeria. In Adeola, A.O. and Ojo, L.O. (eds.) proceeding of the International Biodiversity Observation Year (IBOY) conference University of Agricultural, Abeokuta, Nigeria. $16^{\text {th }}-17^{\text {th }}$ October, 2001. pp. $137-152$.

Appendix 1 - Frequency Distribution of Tree Species Barks bye Markets

\begin{tabular}{|c|c|c|c|c|c|c|c|}
\hline $\begin{array}{l}\text { Local } \\
\text { name }\end{array}$ & Scientific name and family & Iberekodo & Lafenwa & Elega & Omida & Itoku & Kuto \\
\hline Aidan & $\begin{array}{l}\text { Tetrapleura tetraptera } \\
\text { (Sterculiaceae) }\end{array}$ & 3 & 3 & 3 & & & \\
\hline Opepe ira & Albizia ferruginea (Caecalpinioidea) & 5 & 2 & & & & \\
\hline Aaka & $\begin{array}{l}\text { Lecaniodiscus cupanioides } \\
\text { (Anacardiaceae) }\end{array}$ & 4 & & & & & \\
\hline Oganwo & Khaya spp. (Meliaceae) & 5 & 3 & & 4 & & 6 \\
\hline Idigbo & $\begin{array}{l}\text { Terminalia ivorensis } \\
\text { (Combretaceae) }\end{array}$ & 4 & & & & & 4 \\
\hline Ponhan & Lophina alata (Ochinaceae) & 3 & 3 & 4 & 3 & & 3 \\
\hline Akoko & Newbonldia laevis (Bignonaceae) & 4 & 4 & & & 8 & \\
\hline Abafe & $\begin{array}{l}\text { Piliostigma thonningii } \\
\text { (Caesalpinioidae) }\end{array}$ & 5 & 4 & 4 & 3 & 5 & \\
\hline Koko & Theobroma cacao (Sxerculiaceae) & 4 & 4 & 3 & 5 & 4 & 4 \\
\hline Ahun & Alstonia boonei (Apocynaceae) & 4 & 4 & 4 & 5 & 6 & 6 \\
\hline Obi & Cola spp (Sterculiaceae) & & 3 & 2 & 2 & & \\
\hline Ayin & Dialium guinensis (Caesalpinaceae) & & 2 & & & & \\
\hline Atori odo & Glyphea brevis (Flacourtiaceae) & & 5 & 4 & & & \\
\hline Sapo & $\begin{array}{l}\text { Anthocleistha vogellis } \\
\text { (Loganiaceae) }\end{array}$ & & 3 & 3 & & & \\
\hline Apa & Afzelia bella (Caesalpiniodeae) & & 2 & 4 & & 3 & \\
\hline Ogbogbo & $\begin{array}{l}\text { Detarium macrocarpum } \\
\text { (Caesalpinioideae) }\end{array}$ & & 2 & & & & \\
\hline
\end{tabular}




\begin{tabular}{|c|c|c|c|c|c|c|c|}
\hline $\begin{array}{l}\text { Local } \\
\text { name }\end{array}$ & Scientific name and family & Iberekodo & Lafenwa & Elega & Omida & Itoku & Kuto \\
\hline Mango & Mangifera indica (Anacardaceae) & & 4 & 3 & & 4 & \\
\hline Orogbo & Garcinia cola (Guttiferaceae) & & 2 & 2 & 4 & & \\
\hline Omo & Cardia millenii (Boraginaceae) & & 3 & 4 & & & \\
\hline Oruwo & Morinda lucida (Moraceae) & & 3 & 2 & & 8 & \\
\hline Opoto & Ficus capansis (Meraceae) & & 3 & 3 & & 4 & 4 \\
\hline Dongoyaro & Azadirachta indica (Meliaceae) & & 4 & 3 & 2 & & \\
\hline Arin & Diodea reflexa (Caesalpiniaidea & & 2 & 2 & & & \\
\hline Akala & Malacantha alnifolia (Sapotaceae) & & 2 & & & & \\
\hline Gbengbe & Exandex abyssinica (Urimosoideae) & & & 2 & & & \\
\hline Ayo & Morus mesozygia (Moraceae) & & & 3 & 2 & 3 & 2 \\
\hline Asasa & Bridelia micrantha & & & 2 & & & \\
\hline Ire & Funthumia dastica (Apocynaciae) & & & 2 & & & \\
\hline Orira & Lannea welwitsehii (Anacardaceae) & & & 4 & & & \\
\hline Okuku & $\begin{array}{l}\text { Anisophyllea spp. } \\
\text { (Anisophylleaceae) }\end{array}$ & & & 2 & & & \\
\hline Iroko & Milicia excelsa (Meliaceae) & & & 3 & & 10 & \\
\hline Guava & Psidum guajava (Mytaceae) & & & 4 & 3 & 4 & \\
\hline Ose & Adansonia digitata & & & 2 & & & \\
\hline Arere & Triplochiton scleroxylon (Sterculia) & & & 2 & & & \\
\hline Jebo & Entandrophragma utile (Meliaceae) & & & & & & 3 \\
\hline Saparo & $\begin{array}{l}\text { Anthocleistha vogellis } \\
\text { (Loganiaceae) }\end{array}$ & & & & 2 & & \\
\hline Afara & Terminalia superba (Combretaceae) & & & & 1 & & \\
\hline Akomu & $\begin{array}{l}\text { Pyrianthus angolensis } \\
\text { (Myristicaceae) }\end{array}$ & & & & 5 & & \\
\hline Orira & Lannea welwitsehii (Anacardaceae) & & & & 4 & & \\
\hline
\end{tabular}

